\title{
Intangible Resources and Internationalization for the Innovation Performance of Chinese High-Tech Firms
}

\author{
Yuhan Liu, Junic Kim $®$ and Jaewook Yoo * \\ School of Business, Konkuk University, Seoul 05029, Korea \\ * Correspondence: jwyoo@konkuk.ac.kr
}

Received: 29 June 2019; Accepted: 2 August 2019; Published: 6 August 2019

\begin{abstract}
The purpose of this study is to explore the relationships between three intangible resources and the innovation performance of Chinese high-tech firms, and the moderating effect of internationalization on these relationships. We implement a hierarchical multiple regression analysis using data for 274 Chinese high-tech firms. The results show that all three intangible resources, measured by top management team diversity, research and development intensity, and government subsidies, positively influence Chinese high-tech firm innovation performance. We find the relationships between these intangible resources and the innovation performance of Chinese high-tech firms are significantly positively moderated by internationalization. These findings have important implications, as follows. First, they provide evidence of the strategic value of intangible resources and their effects on innovation performance. Second, our results show that increasing internationalization alone does not guarantee performance improvement. Firms should consider their internal and external environments and the complex relationships among factors when they make decisions about internationalization investments. Prior research does not provide an explanation for how internationalization affects performance, because it primarily focuses on the direct relationship between internationalization and performance. This study overcomes this limitation by examining the indirect effect of internationalization on performance.
\end{abstract}

Keywords: intangible resources; internationalization; innovative performance; Chinese high-tech companies

\section{Introduction}

The business environment of the 21st century can be described as having the characteristics of accelerating innovation, globalization of competition, and the collapse of boundaries between industries [1]. In addition, uncertainty in the business environment is intensifying due to the variation in consumer needs and deregulation. It is important for firms to acquire and utilize valuable and rare resources to continue to secure and maintain competitive advantages in this market environment, where competition levels and environmental uncertainties are increasing [2]. From a resource-based view, scholars have divided the types of resources into tangible and intangible resources [3] and stressed the importance of acquiring and utilizing intangible resources that are difficult to imitate and substitute [4].

In addition, many firms face the need for active internationalization to acquire diverse resources that can serve as the basis for sustainable competitive advantages. Internationalization has become a key activity for firms, particularly in developing countries that need to acquire and utilize advanced technologies and resources. Thus, the Chinese government has encouraged and supported the internationalization of Chinese firms [5]. Through the process of market opening and privatization in the early 1990s, firms in China achieved remarkable development and growth based on government 
support and technology acquisition efforts. Facing rapidly changing business environments, they also tried to strengthen their competitiveness through internationalization [6].

High-tech industries are industrial sectors that research, develop, apply, and spread advanced methods and most modern equipment, including industries that are knowledge- and technology-intensive [7]. In 1999, the Ministry of Science and Technology defined high-tech industries as including manufacturing medicine, equipment manufacturing, electric machinery and equipment manufacturing, and manufacturing measuring instruments and office equipment. They later expanded it to include software, telecommunications, electronics, information technology, and biotechnology [8]. In China, high-tech industries are the leading industrial sector in the national economy's development. The firms in these industrial sectors are required to obtain and utilize resources effectively and acquire competitiveness through internationalization [9]. Although the Chinese market has grown rapidly, the skills and capabilities of Chinese firms are still considerably lower than those of multinational firms from advanced economies. Therefore, Chinese firms should acquire and utilize more knowledge and skills through internationalization.

In sum, for high-tech firms in China, the acquisition and utilization of valuable resources and internationalization are essential factors for achieving competitive advantages and growth. Nevertheless, studies on the impact of their resource utilization and internationalization activities on creating competitive advantages are inadequate $[10,11]$. Thus, this study aimed to analyze the relationship between intangible resources and innovation performance, which has been emphasized as having a more significant impact on achieving the competitive advantages of Chinese high-tech firms, and the moderating effect of internationalization on these relationships. The findings of the study intensify the academic value of the resource-based view by providing the empirical evidence for the effects of valuable intangible resources on the innovation performance of firms. They also extend the earlier works on internationalization by providing the indirect effect of internationalization that strengthens the positive relationship between various intangible resources and innovation performance.

\section{Literature Review}

\subsection{Intangible Resources and Competitive Advantage}

Since the late 1980s, the "resource-based view" has emerged as a critical theory for explaining the competitive advantages of firms [10]. Unlike the "industrial organization model," which explains the source of competitive advantages based on the characteristics of the external environment, especially the industrial environment, the "resource-based view" emphasizes the importance of internal resources held by firms to achieve competitive advantages. Scholars supporting the resource-based view argue that a firm is a collection of various resources and the resources held by each firm can be unique, heterogeneous, and difficult to imitate and move [3]. They suggest that four characteristics describe a resource that can be the basis for a sustainable competitive advantage as core competence, as follows: The resource should be (1) valuable, (2) rare, (3) difficult to imitate, and (4) difficult to substitute.

Resource-based view scholars separate a firm's resources into two categories, tangible and intangible. Unlike tangible resources, which have a physical substance, intangible resources, including knowledge, functions, reputation, technology, and relationships, have been considered more important to achieve a sustainable competitive advantage [12]. Intangible resources are framed as tacit information that is difficult to specify in documents. They are difficult for competitors to imitate or substitute [4]. The importance of intangible resources has been further emphasized as globalization and competition have intensified and technological changes have been accelerated [13].

In order to improve performance based on innovation activities, it is necessary to secure and utilize various intangible resources. Intangible resources that are unique and have an intricate social complexity are difficult to imitate or substitute $[14,15]$. These intangible resources are generally divided into three types, human resources, technical resources, and reputation resources [16]. However, other scholars, such as Barney [15] have included culture as an essential type of intangible resource that can 
determine firm competitiveness. In addition, Hall [17] divides intangible resources into two categories, people dependent on resources and people independent of resources. He suggested technical resources and relational resources as specific types of non-human resources [18]. Thus, we focused on three types of intangible resources including human, technical, and relational resources in this study.

\subsection{Internationalization}

With the development of transportation and telecommunications, the global economy has been rapidly consolidating. Accordingly, firms from each country have redoubled their efforts to expand their business activities into overseas markets and to acquire the necessary resources and capabilities. By making inroads into overseas markets, firms can increase their product sales, lower production costs, and strengthen their competitiveness. Internationalization can also serve as a way for knowledge sourcing that is not available in the home market. [19] Therefore, as well as large firms, relatively smalland medium-sized firms have recently been more actively trying to enter overseas markets [20]. In particular, high-tech firms that handle cutting-edge technologies and products often feel the need to advance into overseas markets to get knowledge sources. They often have the difficulty of achieving sufficient expected profits solely from domestic demand if the domestic market is immature or consumers' needs remain low. For these reasons, many firms in the high-tech industrial sector in China have been actively seeking to enter overseas markets [21].

However, prior studies that analyzed the impact of internationalization on firm performance show inconsistent results. In response to these findings, scholars argue that the benefits and costs should be taken into account in each phase of internationalization [22]. For example, in the initial stage of entering overseas markets, the "foreigner liability" of cultural differences and other factors may have a strong impact. Thus, high costs in excess of profits are likely to arise in this stage. However, over time, the various learning and experience effects gained in the process of internationalization can reduce costs and increase profits [23]. Thus, internationalization can provide an opportunity for growth if firms can overcome the costly initial steps [24]. For this purpose, firms should be able to utilize their resources obtained through the management activities in overseas markets.

\subsection{Innovation}

In the face of accelerating competition in the global market, the development of new products and services through innovation is becoming an integral part of firm survival and competitiveness. Many firms have been pushing for innovation-based product development and process improvements to gain competitive advantages [25]. Innovation is seen as an effective means of keeping a firm competitive, even when the firm faces a management crisis $[26,27]$. Thus, the importance of innovation in securing firm competitive advantages has been a major issue, not only for practitioners but also for academics in various fields [28].

In general, innovation is defined as the process of choosing creative ideas and turning them into useful products, services, and operating methods. However, there are also more diverse definitions of innovation. For example, Utterback [29] described innovation as a holistic process of various functional activities, rather than a single act. In addition, Zaltman et al. [30] defined innovation as an overall process in which individuals or social organizations accept and commercialize new ideas. Thus, in this study, we define innovation as "a series of processes that will succeed in the market through the effective performance of new products and services, process development, and management systems as a process of creative destruction". This definition accords to the traditional definition of Schumpeter [31].

\section{Hypotheses Development}

Achieving a competitive advantage and improving performance through innovation requires the acquisition and utilization of various intangible resources [15]. These resources can be classified into intangible and tangible resources and the detailed types of intangible resources include human, 
technical, and relational resources [17]. Especially for Chinese firms, the role of relational intangible resources that can be obtained through the formation of friendly relationships with government stakeholders is very important for success in business [32]. Therefore, in this study, we focus on examining the impacts of three intangible resources of Chinese high-tech firms-human resources, technical resources, and relational resources—on innovation performance.

\subsection{Human Resources-TMT Diversity of Age}

Scholars present human resources as a resource type that can meet the four requirements for becoming a foundation of sustainable competitive advantage [33]. Especially, they emphasized the importance of the TMT (top management team), which directs firm strategic actions and performance, as a representative human resource. Discussions of functions and roles in the TMT began with Hambrick and Mason [34] who insisted on the relationship between the "upper echelon perspective" and strategy. From the upper echelon's perspective, it is very important to understand the various factors that can affect the TMT's cognitive structure, because the TMT chooses the firms' strategic direction based on its cognitive structure [35]. Therefore, many scholars have focused on the effects of TMT diversity on firm strategic direction and performance. TMT diversity presents the degree of heterogeneity of the characteristics of TMT members [36]. Early studies on TMT diversity focused on the analysis of the effects of TMT diversity as a single construct [37]. However, because the various components that make up the TMT's diversity can have a discriminatory effect on the firms' strategy and performance, TMT diversity should not be considered as a single construct [38]. Therefore, this study focuses only on TMT age diversity, which is expected to have the most significant impact on the firm's innovation activities and performance.

In TMT with members of diverse ages, there is a significant difference between older and younger members regarding risk-taking propensity and capacity [39]. Specifically, younger members tend to pursue new things more aggressively than older members, respond more proactively to environmental changes, and seek higher levels of risk [40]. In addition, compared with older managers, younger managers are more likely have recent information and technical knowledge [41]. On the other hand, older managers are likely to have a wide range of knowledge and information based on their rich experience in the industrial sector, which can provide potential opportunities for capture and utilization of market opportunities [42]. In addition, they often have valuable practical knowledge and know-how based on their experience [43].

In fact, the implementation of successful innovation requires the use of diverse experience, knowledge, and networks inside and outside the industry, along with new perspectives on breaking stereotypes and proactive attitudes toward environmental change. Therefore, it would be preferable for the TMT to consist of members of more diverse ages [44]. In this regard, firms in China are also aware of the importance of human resources. They consider the capabilities, knowledge, and experience of top managers as important factors for their competitiveness and growth [19]. In addition, they make efforts to improve innovation performance by including young members in their TMT and creating synergy with existing older and experienced team members [45]. Therefore, the following hypothesis about the relationship between the age diversity of the TMT and innovation performance of Chinese high-tech firms is established.

Hypothesis 1. There is a positive relationship between the age diversity of the TMT and the innovation performance of Chinese high-tech firms.

\subsection{Technical Resources-RED Investments}

A technical resource is an asset of a firm that can be used to develop new products or improve the production process. It has drawn the attention of many researchers as an intangible resource that meets the four requirements of becoming a foundation for sustainable competitive advantage. Most prior studies have measured technological resources using the level of R\&D (research and development) 
investment, because it is very difficult to directly measure technological resources [46]. In fact, the use of this substitute has sufficient validity, as firms acquire technological resources such as technical knowledge, know-how, and advanced systems needed for innovation through R\&D investment [47,48]. Therefore, in this study, the level of technical resources of high-tech firms was measured as the investment in R\&D.

In fact, many Chinese firms were not fully aware of the importance of technological resources until early 2000. Even firms in the high-tech industry whose acquisition and utilization of technical resources is critical for creating sustainable competitive advantages did not fully recognize the importance of technological resources. Rather than developing new technologies, they focused on imitating the technology already developed by the firms in developed countries [25]. However, the lack of firm-specific technology capabilities weakened the competitiveness of China's high-tech industrial sector as well as firm competitiveness. Thus, to overcome limitations and secure sustainable competitiveness, high-tech firms in China have increased their R\&D investment for the acquisition of technological resources. With the increase in $R \& D$ investment, technological resources have been considered key factors for innovation and creation by high-tech firms $[49,50]$. Thus, the following hypothesis about the relationship between technological resources and the innovation performance of Chinese high-tech firms is proposed.

Hypothesis 2. There is a positive relationship between RED investment and the innovation performance of Chinese high-tech firms.

\subsection{Relational Resources-GuanXi}

As a unique cultural phenomenon that has been handed down for thousands of years, "GuanXi" is a distinctive component of Chinese culture [51]. GuanXi has received the attention of scholars and working-level officials throughout its long history. The word GuanXi, which consists of guan and $x i$, is usually translated as "relationship" or "connection" [52]. In prior studies, GuanXi was defined as "networked relations" [53], "social capital" [54], "social connections", "a support relationship by reciprocal obligation" [55], "personal relationships gained throughout life as a social act" [56], and "social connectivity of more than two people" [57]. Among these, we followed the definition of Kim et al. [56]. Thus, in this study we define GuanXi between the Chinese government and high-tech firms as a "support relationship by mutual obligation".

Managers of Chinese firms regard GuanXi as an important resource to be used in corporate management. Accordingly, prior studies (e.g., [58]) claim that GuanXi is the most important resource and key factor needed to do business in China. GuanXi is a valuable resource that can help firms achieve a competitive advantage. Its characteristics include non-mobility, complexity, interconnection, and collective efficiency [59]. Many scholars have also presented empirical results showing that GuanXi plays a key role in acquiring resources and building competitiveness. They have focused on identifying the relationship between GuanXi with various stakeholders and the performance of firms $[51,56,60]$.

GuanXi enables Chinese firms to acquire the resources necessary for effective firm activities [61]. Particularly, firms can secure a superior network for sales, access to rare resources or infrastructure, and get direct and indirect subsidies through GuanXi with the government. On the other hand, there are some scholars who have noted the potential negative impacts of GuanXi. They argued that subsidies obtained from GuanXi could result in excessive government pressure and monitoring, hindering the autonomous decision-making and management of firms [62].

However, for Chinese high-tech firms, acquiring government subsidies based on GuanXi with the government can directly lead to investments in innovation. R\&D investments are often required to improve innovation performance to compete with large global firms. However, R\&D investments involve a high level of risk and uncertainty for expected results. Therefore, from the standpoint of Chinese firms, it is very important to acquire capital through government support, rather than raising all the capital for innovative investment on their own. GuanXi held by firms offers the opportunity to acquire financial resources, as well as valuable information for innovation. Such resources and 
information can be a source of competitive advantage that is difficult for competitors to imitate. Thus, the following hypothesis is established regarding the relationship between GuanXi with the government and the innovation performance of Chinese high-tech firms.

Hypothesis 3. There is a positive relationship between Guanxi and innovation performance in Chinese high-tech firms.

\subsection{Moderating Effect of Internationalization}

In highly competitive business environment, firms have to proactively adapt to environmental changes in the global market. Thus, internationalization has become an essential requirement for survival, as well as for the growth of firms. Accordingly, many Chinese firms have tried to achieve international level competitiveness by carrying out active strategies in overseas markets [8].

Through internationalization, firms can create economies of scale, economies of scope, and the learning effect. If the domestic market is not large enough, they can create new demand markets and spread their risk by advancing into overseas markets [9]. They can also improve their structure through active internationalization, which can realize the need for continued technological development and innovation and organizational management capabilities in different overseas markets [8]. Firms can strengthen their competitiveness and improve performance by acquiring and utilizing valuable human, technological, and financial resources in overseas markets.

Despite the rapid growth of the Chinese market, the development and spread of valuable resources in China falls far short when compared to advanced countries [63]. To overcome this limitation, many Chinese firms have entered international markets [61]. High-tech firms especially have difficulty covering high-level R\&D costs when operating solely in domestic markets. They need to learn and utilize new knowledge and technology in overseas markets. Thus, many Chinese firms put a great amount of time and effort into internationalization. However, there are not many studies that focus on the impact of internationalization on the performance of Chinese high-tech firms [64]. Furthermore, even some studies conducted on this relationship present conflicting results. Thus, our study focuses not on the direct effect of internationalization on the innovation performance of Chinese high-tech firms, but on an analysis of the indirect effects that internationalization could have on innovation performance through interaction with the three intangible resources-human resources, technical resources, and relational resources.

Regarding human resources, the internationalization of Chinese high-tech firms is expected to strengthen the competitiveness of TMT for innovation performance. In particular, through internationalization, younger top managers can acquire new and broader knowledge, information, and technology more quickly, which enhances the capabilities for innovation. The enhanced capabilities of younger top managers is beneficial for improving the innovation performance of firms through the process of working with older and more experienced top managers. Thus, the following hypothesis has been established regarding the effect of internationalization on the relationship between the age diversity of TMTs and the innovative performance of Chinese high-tech firms.

Hypothesis 4a. Internationalization of Chinese high-tech firms will strengthen the positive relationship between the age diversity of TMTs and the innovation performance of Chinese high-tech firms.

Technical resources are the most important ones for high-tech firms to gain a competitive advantage. Internationalization is not only beneficial for raising new technical resources but also for strengthening the effectiveness of existing resources [57]. Specifically, internationalization can have a positive effect on understanding and experiencing technological resources that are difficult to obtain in the domestic market [57]. Moreover, resources acquired by building and utilizing diverse networks in international markets can help firms develop differentiated new technologies that competitors cannot easily imitate [62]. Thus, this study establishes the following hypothesis regarding the effect of internationalization on the relationship between R\&D investment and the innovation performance of Chinese high-tech firms. 
Hypothesis $4 \mathbf{b}$. Internationalization of Chinese high-tech firms will strengthen the positive relationship between RED investment and the innovation performance of Chinese high-tech firms.

As described earlier, the Chinese government has been increasing its support for globalization to strengthen the international-level competitiveness of Chinese firms [65]. A firm more likely receives support if it has GuanXi with the government. It can reduce its financial burden for R\&D investment, as well as for internationalization, by obtaining government subsidies. It can also reduce risk-averse tendencies if it pursues innovation and internationalization using government subsidies. However, all investment cannot be successful for innovation performance. To intensify the effectiveness and productivity of government subsidies, firms should acquire valuable knowledge and information from overseas markets [9]. This, in turn, can enhance the positive effect of government subsidies on the innovation performance of firms. Thus, the following hypothesis is established regarding the impact of internationalization on the relationship between government subsidies and the innovation performance of Chinese high-tech firms.

Hypothesis 4c. The internationalization of Chinese high-tech firms will strengthen the positive relationship between government subsidies and the innovation performance of Chinese high-tech firms.

Figure 1 presents the research model showing the relationship among the key variables presented in the hypotheses.

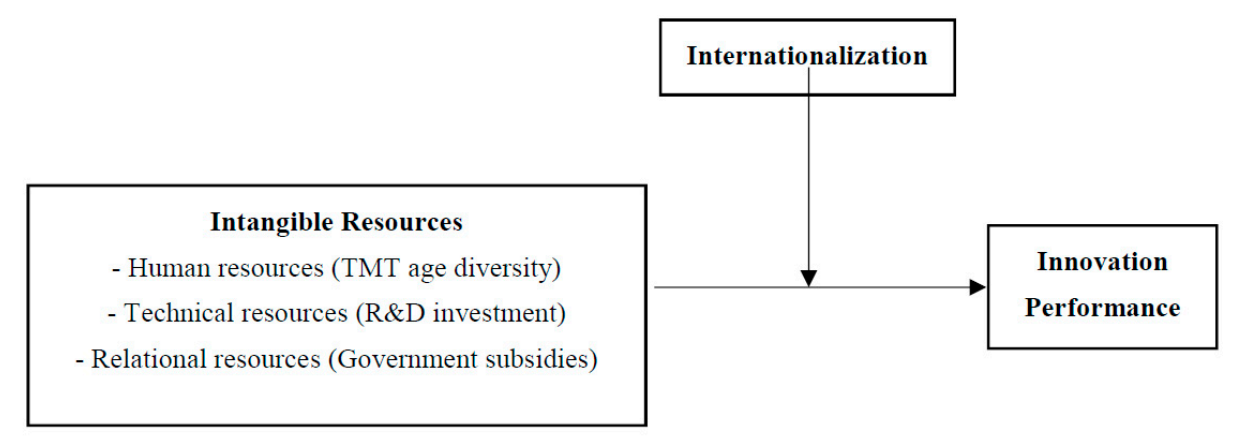

Figure 1. Research model.

\section{Analysis}

\subsection{Data Collection and Sample}

The firms listed on China A stock in China's high-tech industrial sector in 2016 were selected as the research sample. Information on TMT ages, R\&D expenses, government subsidies, overseas sales, number of patents, number of employees, and total assets of sample firms were collected from the CSMAR and the WIND databases. After excluding firms with missing information, the final sample included 274 firms.

\subsection{Measurement of Variables}

(1) Independent Variables—Intangible Resources

TMT Diversity: Article 217 of the Chinese Company Law defines the TMT as the person in charge of identifying important information for corporate management. Accordingly, prior studies have included managers with titles of chief executive officer, deputy prime minister, general accountant, and chief financial officer as members of the TMT [66]. We follow the definition of TMT used in these prior studies. The age diversity of the TMT was measured by an indexing method based on entropy measurement [67]. Specifically, the members were divided into age groups of younger than 40 years 
old , 41-45, 46-50, 51-55, and older than 56 years. Then, diversity was measured using the following formula [67].

$$
\text { TMT Diversity }=-\sum_{i=1}^{s} P i \times \operatorname{Ln}(P i) .
$$

R\&D Investment: Since firms can acquire technical resources through R\&D investment, R\&D intensity has been used for a typical proxy for the extent of a firm's technological resources [47]. Therefore, in this study, the level of technological resources of Chinese high-tech firms was measured by R\&D intensity, calculated by R\&D investment relative to sales in 2016. The final measurement included in the analysis was the natural logarithmic value of R\&D intensity, because of the asymmetry of the distribution of R\&D investment [68].

Government Subsidies: Relational resources, another key resource for the innovation of Chinese high-tech firms, were measured with a particular focus on relationships with the government, as one of the various stakeholders described earlier. Specifically, government subsidies were obtained from the annual reports of the sample firms included in the analysis as a proxy for relational resources. We took the natural logarithm of government subsidies because of the asymmetry of the distribution of government subsidies.

\section{(2) Moderating Variable-Internationalization}

The level of internationalization of the sample firms was measured through various indicators, including the portion of overseas assets [69], the portion of overseas sales [21], the portion of overseas employees, and the number of overseas subsidiaries [70]. Some prior studies have indexed and utilized composite indicators of various measures. For example, in a study of service firms, Contractor et al. [20] measured the internationalization level of sample firms as a composite index of their overseas sales, the proportion of overseas employees, and the proportion of overseas subsidiaries. However, researchers argued that the use of composite indicators is not suitable for comprehensive measurement of the impact of internationalization through various methods, such as exports and contracts [71]. In this study, we adopt the same approach to measure the internationalization level of Chinese high-tech firms.

\section{(3) Dependent Variable-Innovation Performance}

Patents have been used in many prior studies as a proxy for innovation performance. Particularly, the patents in high-tech industries have been considered very appropriate as a proxy for innovation because they can be an effective way of maintaining a technological edge by protecting the company's proprietary knowledge and technology [72]. Therefore, the innovation performance of Chinese high-tech firms, which is the dependent variable in this study, was measured by the number of patents successfully registered with the Chinese Patent and Trademark Office in 2016 [73]. We dropped the firms that did not register any patent in 2016 from our sample. The minimum and maximum values were 1 and 213. The average and standard deviation were 81.49 and 63.4 respectively.

\section{(4) Control Variables—Firm Size, Firm Age, and Type of Industry}

In the empirical analysis, we controlled for the effects of firm size, firm age, and the type of industry, which could affect the dependent variable of the study. Prior studies have suggested that larger firms have more resources to spare, so there is a high possibility of more aggressive investment in innovation and better innovation performance [29]. On the other hand, other studies have suggested that larger firms may invest less in innovation activities due to the inertia within the organization [74]. Thus, the effect of firm size, measured by log values of the total number of employees, was controlled in the regression analysis.

In general, younger firms innovate and develop new products more strongly, while older firms have a greater tendency to hedge against risks and uncertainties [75]. Thus, the effect of firm age, measured in years from the firm's establishment, was controlled in the analysis. In addition, the effect 
of industrial types, measured by a dummy variable (manufacturing industry $=1$, non-manufacturing industry $=0$ ), was controlled in the regression analysis $[76,77]$.

\section{Results}

For the analysis of the hypotheses, hierarchical multiple regression analysis was implemented. We used SPSS 24 as a tool to conduct statistical analysis. Descriptive statistics and Pearson correlations among the variables are presented in Table 1 . The correlation coefficients between firm size and several other variables seem high. Thus, we conducted VIF (Variance Inflation Factor) analysis to check for multicollinearity. The results showed that the VIF values for all variables, including firm size, were all lower than the threshold of five. Therefore, we conclude multicollinearity is not a significant concern in hierarchical multiple regression analysis.

Table 1. Descriptive statistics and Pearson correlation matrix $(n=274)$.

\begin{tabular}{|c|c|c|c|c|c|c|c|c|c|c|}
\hline & Mean & S.D. & VIF & 1 & 2 & 3 & 4 & 5 & 6 & 7 \\
\hline Firm size & 3.44 & 0.44 & 3.171 & 1 & & & & & & \\
\hline Firm age & 9.48 & 5.11 & 1.254 & $0.41^{* *}$ & 1 & & & & & \\
\hline Type of industry & 1.09 & 0.29 & 1.047 & -0.10 & 0.06 & 1 & & & & \\
\hline TMT age diversity & 28.22 & 12.66 & 1.303 & $0.43^{* *}$ & $0.27 * *$ & 0.02 & 1 & & & \\
\hline R\&D intensity & 7.95 & 0.49 & 3.063 & $0.76^{* *}$ & $0.32 * *$ & $-0.12 *$ & $0.04^{* *}$ & 1 & & \\
\hline $\begin{array}{l}\text { Government } \\
\text { subsidies }\end{array}$ & 7.30 & 0.58 & 1.976 & $0.60^{* *}$ & $0.29 * *$ & -0.08 & $0.34^{* *}$ & $0.66^{* *}$ & 1 & \\
\hline Internationalization & 0.13 & 0.18 & 1.735 & $0.22 * *$ & 0.07 & 0.05 & 0.07 & 0.10 & -0.05 & 1 \\
\hline
\end{tabular}

Table 2 presents the results of a hierarchical multiple regression analysis conducted on 274 sample firms. As the base model, Model 1 includes all control variables only. According to the results of Model 1 , there is a significantly positive relationship between firm size and innovation performance $(\beta=0.347$, $p<0.05)$. On the other hand, firm age and industry type did not reveal any significant relationship with innovation performance.

Table 2. Hierarchical multiple regression analysis results $(n=274)$.

\begin{tabular}{|c|c|c|c|c|c|}
\hline & Model 1 & Model 2 & Model 3 & Model 4 & Model 5 \\
\hline Firm size & $0.347^{* * *}(5.479)$ & $-0.018(-0.202)$ & $0.244^{* * *}(3.628)$ & $0.065(0.724)$ & $0.171^{* *}(2.227)$ \\
\hline Firm age & $0.009(0.142)$ & $-0.030(-0.506)$ & $-0.018(-0.297)$ & $0.007(0.114)$ & $0.013(0.206)$ \\
\hline Type of industry & $-0.002(-0.040)$ & $0.001(0.017)$ & $-0.038(-0.654)$ & $0.017(0.314)$ & $-0.011(-0.193)$ \\
\hline TMT age diversity & & $0.226^{* * *}(3.736)$ & $0.190 * * *(2.547)$ & & \\
\hline R\&D intensity & & $0.258^{* * *}(2.845)$ & & $0.206^{* *}(2.044)$ & \\
\hline $\begin{array}{l}\text { Government } \\
\text { subsidies }\end{array}$ & & $0.144^{* *}(1.963)$ & & & $0.134(1.542)$ \\
\hline Internationalization & & & $-0.263 *(-1.775)$ & $\begin{array}{l}-2.965^{* * *} \\
(-3054)\end{array}$ & $\begin{array}{l}-1.928^{* * *} \\
(-2.583)\end{array}$ \\
\hline $\begin{array}{l}\text { Int } \times \text { TMT } \\
\text { Diversity }\end{array}$ & & & $0.289 *(1.834)$ & & \\
\hline Int $\times$ R\&D & & & & $2.999^{* * *}(3.067)$ & \\
\hline $\begin{array}{l}\text { Investment } \\
\text { Int } \times \text { Gov. } \\
\text { Subsidies }\end{array}$ & & & & & $1.967^{* * *}(2.636)$ \\
\hline$R$-squared & 0.123 & 0.235 & 0.190 & 0.209 & 0.186 \\
\hline$R$-sq Changed & 0.113 & 0.217 & 0.010 & 0.027 & 0.021 \\
\hline F value & $12.609 * * *$ & $13.641 * * *$ & $10.437^{* * *}$ & $11.744^{* * *}$ & $10.191 * * *$ \\
\hline$F$ change & $12.609 * * *$ & $12.993 * * *$ & $3.364 *$ & $9.403^{* * *}$ & $6.950 * * *$ \\
\hline
\end{tabular}


According to the findings in model 2, which includes both control and main variables, TMT age diversity has a significantly positive relationship with innovation performance $(\beta=0.226, p<0.01)$. In addition, $R \& D$ intensity $(\beta=0.258 p<0.01)$ and government subsidies $(\beta=0.144, p<0.05)$ also have significantly positive relationships with innovation performance. Thus, hypothesis 1 , hypothesis 2 , and hypothesis 3 , regarding the relationships between the three types of intangible resources and the innovation performance of Chinese high-tech firms, were all supported.

Interaction variables enter in the third, fourth, and fifth models. The results of Model 3, which analyzes the interaction effects of internationalization with TMT age diversity, reveal that internationalization of Chinese high-tech firms strengthens the positive relationship between TMT age diversity and innovation performance at $p<0.1$, thus supporting hypothesis 4 a.

A conditioned effect analysis using Process macro was additionally conducted to examine how the impacts of TMT age diversity on innovation performance differ according to the levels of internationalization. A conditional effect analysis is a verification technique that divides the moderation variables into a total of 23 values and calculates the significance level of interaction effects at each value. It is a relatively new technique in strategic management and innovation research. However, it has been often used in the prior research of marketing [78,79].

The findings in Table 3 show that the positive impact of TMT age diversity on innovation performance is higher in groups with a high level of internationalization $(t=2.547, p<0.01)$ than in groups with a low-level of internationalization $(t=4.559, p<0.01)$. In addition, a firm with high levels of both TMT diversity and internationalization achieved a higher level of innovation performance than the firms with only one component at a higher level or both at a lower level. Figure 2 illustrates this conditional effect of interaction and the relationship between TMT age diversity and innovation performance.

Table 3. Conditional effect of age diversity.

\begin{tabular}{lccccccc}
\hline & & B & SE & $t$ & $p$ & LLCI & ULCI \\
\hline \multirow{3}{*}{$\begin{array}{l}\text { TMT age } \\
\text { diversity }\end{array}$} & $-1 S D$ & 2.942 & 1.155 & 2.547 & 0.011 & 0.667 & 5.217 \\
\cline { 2 - 7 } & Mean & 4.010 & 0.958 & 4.183 & 0.000 & 2.123 & 5.898 \\
\cline { 2 - 7 } & $+1 S D$ & 5.438 & 1.192 & 4.559 & 0.000 & 3.090 & 7.787 \\
\hline
\end{tabular}

Note: 1SD stands for one Standard Deviation.

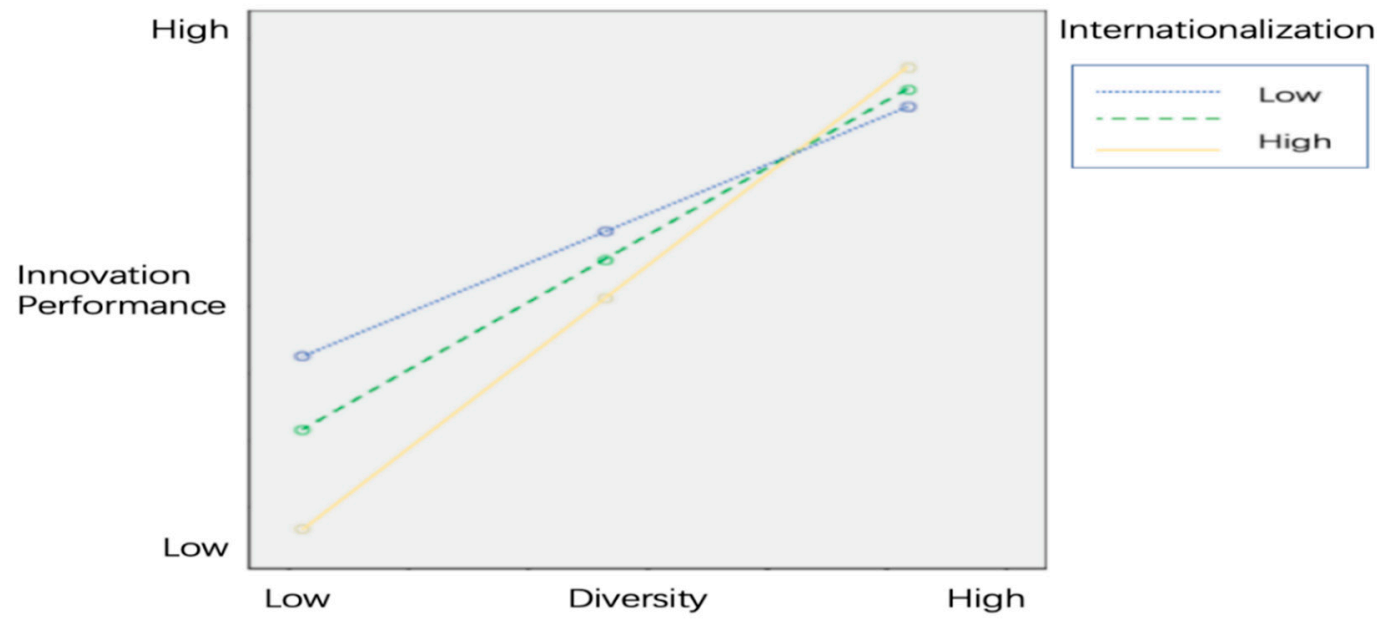

Figure 2. The interaction between TMT age diversity and internationalization.

The findings in Model 4, which analyzes the interaction effects of internationalization with $R \& D$ intensity on innovation performance, shows that internationalization strengthens the positive 
relationship between $R \& D$ intensity and the innovation performance of Chinese high-tech firms $(\beta=2.999, p<0.01)$. Thus, hypothesis $4 \mathrm{~b}$ was supported. Furthermore, the findings of the conditional effect analysis in Table 4 show that R\&D investment has a different effect on innovation performance depending on the level of internationalization. They show that the effect of R\&D investment on innovation performance is higher in the group with a high level of internationalization $(t=5.362$, $p<0.01)$ than in the group with a low level of internationalization $(t=2.044, p<0.05)$. These findings show that maintaining both R\&D investment and internationalization at higher levels results in a greater innovation performance. Figure 3 illustrates this relationship.

Table 4. Conditional effect of R\&D investment.

\begin{tabular}{cccccccc}
\hline & & B & SE & $\mathbf{t}$ & $\mathbf{p}$ & LLCI & ULCI \\
\hline \multirow{2}{*}{$\begin{array}{c}\text { R\&D } \\
\text { investment }\end{array}$} & $-1 S D$ & 82.393 & 40.308 & 2.044 & 0.041 & 3.037 & 161.761 \\
\cline { 2 - 7 } & Mean & 137.46 & 34.081 & 4.033 & 0.000 & 70.360 & 204.564 \\
\cline { 2 - 7 } & $+1 S D$ & 221.06 & 39.362 & 5.362 & 0.000 & 133.562 & 288.563 \\
\hline
\end{tabular}

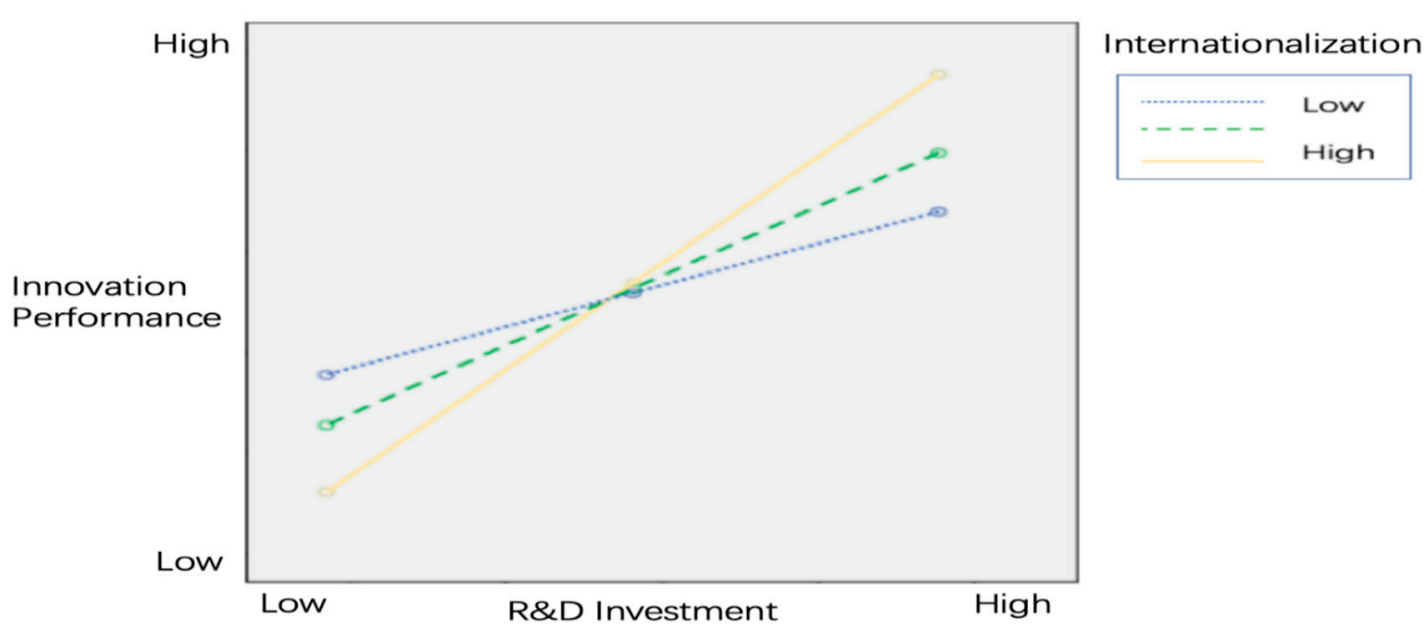

Figure 3. The interaction between $R \& D$ Investment and Internationalization.

The findings in Model 5, which analyzes the interaction effect of internationalization with government subsidies on innovation performance, show that internationalization strengthens the positive relationship between government subsidies and the innovation performance of Chinese high-tech firms $(\beta=1.967, p<0.1)$. Thus, hypothesis $4 \mathrm{c}$ was supported. The findings of the conditional effect analysis in Table 5 indicate that the effect of government subsidies on innovation performance significantly differ at different levels of internationalization. In particular, they reveal that the effects of government subsidies on the innovation performance of Chinese high-tech firms is not significant in groups with low levels of internationalization $(t=1.541, p=1.12)$, but is significantly positive in groups with high levels of internationalization $(t=4.549, p<0.01)$. This finding shows that firms with high levels of both government subsidies and internationalization generate a relatively higher innovation performance than those that do not. Figure 4 is a graphical analysis of these relationships.

Table 5. Conditional effect of government subsidies.

\begin{tabular}{|c|c|c|c|c|c|c|c|}
\hline & & B & SE & $t$ & $p$ & LLCI & ULCI \\
\hline \multirow{3}{*}{$\begin{array}{c}\text { Government } \\
\text { subsidies }\end{array}$} & $-1 S D$ & 45.015 & 29.201 & 1.541 & 0.124 & -12.478 & 102.510 \\
\hline & MEAN & 84.597 & 24.029 & 3.520 & 0.000 & 37.285 & 131.909 \\
\hline & $+1 S D$ & 137.50 & 30.224 & 4.549 & 0.000 & 77.996 & 197.014 \\
\hline
\end{tabular}




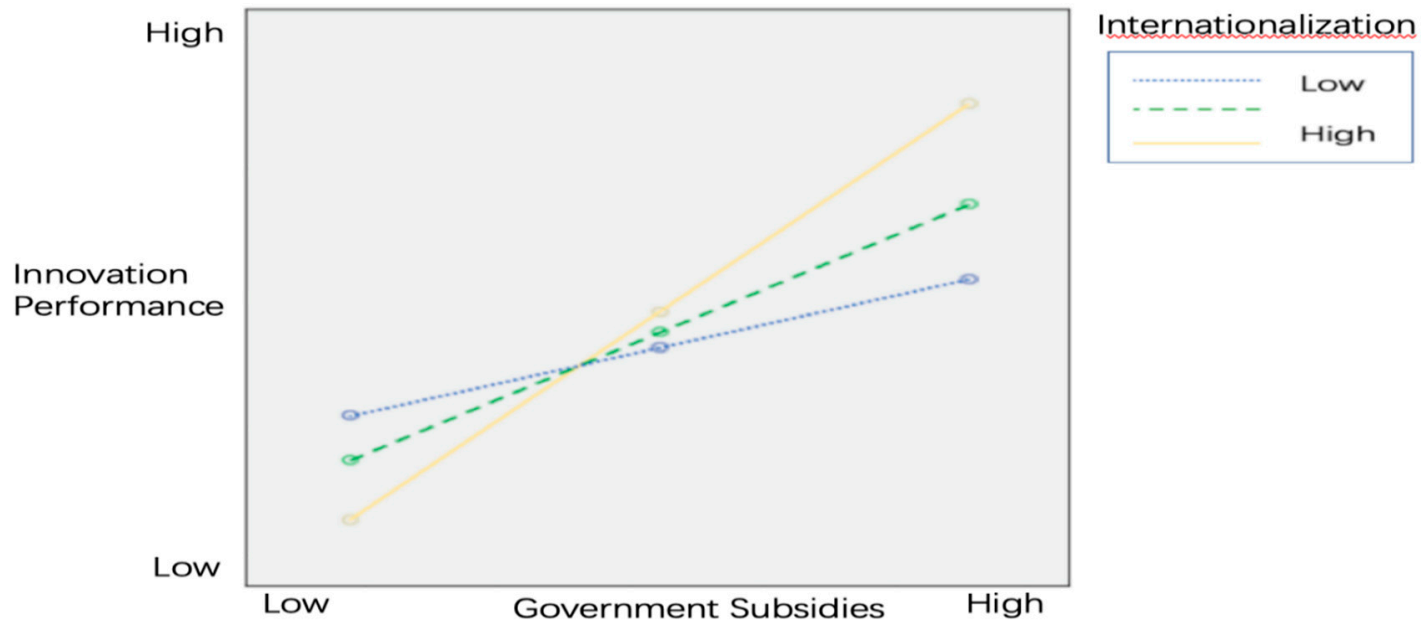

Figure 4. Interaction between government subsidies and internationalization.

\section{Conclusions}

The purpose of this study was to analyze the relationship between three intangible resources and the innovation performance of Chinese high-tech firms and the moderating effect of internationalization on these relationships. The empirical context of this study is listed high-tech Chinese firms in 2016. The findings of the hierarchical multiple regression show that there is a significantly positive relationship between all three types of intangible resources and the innovation performance of Chinese high-tech firms. On the other hand, the result of regression analysis reveals a negative relationship between internationalization and innovation performance. Although not established as a hypothesis, this result contradicts the findings in the prior studies that presented a positive or no direct relationship between internationalization and innovation performance [80,81]. It presents that if Chinese firms do not have sufficient intangible resources that are valuable, rare, and difficult to imitate and substitute, they cannot achieve a high innovation performance even though they are active in internationalization. Rather, internationalization might increase the uncertainty faced by firms and thus lead to a decrease in innovation performance. On the other hand, internationalization can strengthen the positive relationship between each intangible resource and the innovation performance of Chinese high-tech firms. These findings present that although internationalization alone cannot improve innovation performance, it can indirectly enhance innovation performance if the firm possesses and utilizes valuable intangible resources.

The results of this study have certain implications for firms that operate in high-tech industries where the pace of innovation and imitation is high and continued investment in R\&D is essential. Specifically, they provide the following important academic and practical implications. First, this study delivers academic value by providing empirical evidence of the effects of intangible resources that meet the four conditions for becoming the basis of a sustainable competitive advantage, which has been emphasized from a resource-based view. The findings also provide useful information for high-tech firms who need to strengthen their competitiveness by acquiring and utilizing core resources and for policy makers who need to prepare effective supporting methods for those firms.

Second, although there are many prior studies analyzing the impact of internationalization on firm performance, they have presented conflicting findings. In addition, they failed to explain how internationalization improves firm performance. This study addresses these limitations. Although China has recently experienced rapid growth, it is still an emerging economy market with relatively little technology or knowledge compared to the markets in advanced economies. Thus, Chinese firms have made great efforts to overcome the limits of their own markets by advancing into overseas markets. However, the findings of this study suggest that the entry into overseas markets without sufficient internal resources for innovation could have a negative impact on the innovation performance 
of Chinese high-tech firms. Internationalization could have a positive impact on firm innovation performance only if the acquisition and utilization of valuable and rare internal resources are assumed. This finding implies that high-tech firms in China should pursue internationalization after carefully considering the combined influence of their diverse internal resources.

This study has the following limitations, which can be overcome by future research. First, in hierarchical regression analysis, we did not include the potential effects of TMT diversity in tenure, professional background, gender, etc. Although it is appropriate to adopt age diversity as a measurable variable that could have a significant impact on a firm's innovation performance [39,82], future studies that measure and analyze more diverse elements of TMT diversity would enhance the reliability of the findings of this study and provide additional valuable information.

Second, there is a potential two-way causality running from internationalization to innovation performance and vice versa. [83] Furthermore, there is evidence that more productive plants, which are linked to higher innovation performance, do more exporting in practice. Although we did not make and explore the direct causal relationship between internationalization and innovation performance, this potential problem of reverse causality should be recognized, especially in the interpretation of the findings. Future research might be able to successfully control this potential two-way causality by adopting a convincing econometric analysis.

Third, this study focused on the effects of three intangible resources-human, technological, and relationship resources-as intangible resources that could be used to create a firm's sustainable competitive advantage. However, the effects of reputational resources, another intangible resource that could have a significant impact on innovation performance through interrelationships with internationalization, were not included due to the limitations in data collection and measurement. Further practical implications may be provided if a future study that includes those variables is carried out. As in previous research, this study used the number of patents as a proxy for innovation performance [84-86]. However, innovation activities that do not register a patent may also lead to valuable technological improvements of firms. Further implications may be provided if a future study uses proxy or primary data that captures the effects of all valuable technological improvements, whether or not a patent is registered.

Fourth, GuanXi, an intangible relational resource that can have a significant impact on the management activities and performance of Chinese firms, is difficult to define in a single clear sense. Thus, referring to prior studies, GuanXi was defined as a "support relationship by mutual obligation" and measured as government subsidies. However, in practice, GuanXi could be defined as a more comprehensive concept and implemented in various forms. Thus, if the effects of GuanXi as an intangible relational resource were measured and analyzed from a more comprehensive perspective, it would provide additional valuable implications.

Finally, because the research target of this study was limited to Chinese high-tech firms, the final sample was limited to 274 firms. If future research is carried out to expand the research target to other industrial sectors and/or multiple years, the limitations of the sample size will be overcome. Furthermore, the generalizability and value of the findings can be enhanced.

Author Contributions: Conceptualization and methodology, Y.L.; formal analysis, investigation, data curation, and validation, Y.L. and J.Y.; writing—original draft preparation, review, and editing, J.K.; visualization, supervision, and project administration, Y.L., J.K., and J.Y.

Conflicts of Interest: The authors declare no conflicts of interest.

\section{References}

1. Kwon, O.O.; Lee, K.T. An Exploratory Study on the Relationship between Environment, CEO, Strategy, and HRM of Small and Medium Enterprises. Korean Manag. Asso. 2009, 8, 1-19.

2. Bae, J.S.; Park, O.W. Strategic Human Resource Management and Organizational Innovation: Comparative Analysis of Exploratory Innovation Performance and Innovative Innovation Performance. Pers. Organ. Res. 2005, 13, 147-186. 
3. Chatterjee, S.; Wernerfelt, B. The link between resources and type of diversification: Theory and evidence. Strateg. Manag. J. 1991, 12, 33-48. [CrossRef]

4. Lee, J.Y. Incremental Innovation and Radical Innovation: The Impacts of Human, Structural, Social, and Relational Capital Elements. Ph.D. Thesis, Michigan State University, East Lansing, MI, USA, 2011.

5. Johanson, J.; Vahlne, J.E. The internationalization process of the firm-A model of knowledge development and increasing foreign market commitments. J. Int. Bus. Stud. 1977, 8, 23-32. [CrossRef]

6. Schilling, M.A. Technological lockout: An integrative model of the economic and strategic factors driving technology success and failure. Acad. Manag. Rev. 1998, 23, 267-284. [CrossRef]

7. Song, J.Y.; Yoon, W.J. A Study on Knowledge Transfer Through Mergers and Acquisitions in Knowledge-Intensive Industries. Korean Manag. Rev. 2005, 32, 349-373.

8. Wu, J.F.; Qiao, L.; Yang, Z.N. Research on the Relationship between Internationalization Level, R\&D Management and Technological Innovation Performance of Emerging Market Enterprises. J. Uni. Int. Bus. Econ. 2016, 4, 140-151.

9. Zhang, J.; Xiong, L. Empirical Research on Enterprise Technology Innovation, Senior Management Team Human Capital and Enterprise Internationalization Performance. Southwest Uni. Financ. Econ. 2016, 3, 1-47.

10. Seong, T.G. A Firm Size-Innovative Activity Relationship: An Empirical Study of the Korean Manufacturing Industry. Asia Pac. J. Small Bus. 2003, 25, 305-325.

11. Jung, J.S.; Moon, H.C. Stepwise consideration of cluster evolution and creation of new global association cluster. Manag. History 2008, 46, 77-104.

12. Park, W.; Park, S.K.; Lee, C.S. The relation between intangible resources and sustainability of competitive advantage. J. Ind. Econ. Bus. 2007, 20, 2265-2286.

13. Andriessen, D. IC valuation and measurement: Classifying the state of the art. J. Intellect. Cap. 2004, 5, 230-242. [CrossRef]

14. Dierickx, I.; Cool, K. Asset Stock Accumulation and the Sustainability of Competitive Advantage: Reply. Manag. Sci. 1989, 35, 1514. [CrossRef]

15. Barney, J. Firm resources and sustained competitive advantage. Strateg. Manag. J. 1991, 17, 99-120. [CrossRef]

16. Balkin, D.B.; Markman, G.D.; Gomez-Mejia, L.R. Is CEO Pay in High-Technology Firms Related to Innovation? Aca. Manag. J. 2000, 43, 1118. [CrossRef]

17. Hall, R. A framework linking intangible resources and capabilities to sustainable competitive advantage. Strateg. Manag. J. 1993, 14, 607. [CrossRef]

18. Fernández, E.; Montes, J.M.; Vázquez, C.J. Typology and strategic analysis of intangible resources: A resource-based approach. Technovation 2000, 20, 81-92. [CrossRef]

19. Aw, B.Y.; Roberts, M.J.; Xu, D.Y. R\&D Investment, Exporting, and Productivity Dynamics. Am. Econ. Rev. 2011, 101, 1312-1344.

20. Kang, S.M. The impact of firm internationalization on performance. Int. Bus. Rev. 2011, 15, 69-86. [CrossRef]

21. Xi, L.J. Incurrence of fiscal and taxation policies, development of high-tech industries, and adjustment of industrial structure. Seeking Truth 2015, 12, 89-92.

22. Qian, G.; Khoury, T.A.; Peng, M.W.; Qian, Z. The performance implications of intra-and inter-regional geographic diversification. Strateg. Manag. J. 2010, 31, 1018-1030. [CrossRef]

23. Ruigrok, W.; Wagner, H. Internationalization and performance: An organizational learning perspective. Manag. Int. Rev. 2003, 43, 63-84.

24. Larson, E.B.; Kukull, W.A.; Buchner, D.; Reifler, B.V. Adverse drug reactions associated with global cognitive impairment in elderly persons. Ann. Intern. Med. 1987, 107, 169-173. [CrossRef] [PubMed]

25. Danneels, E. The dynamics of product innovation and firm competences. Strateg. Manag. J. 2002, 23, 1095-1121. [CrossRef]

26. Lee, S.H.; Park, K.T. An empirical study on the relations among management innovation, impact from crisis, and resilience power. Corp. Strateg. Stu. 2012, 19, 177-191.

27. Egbetokun, A.; Oluwadare, A.; Ajao, B.; Jegede, O. Innovation systems research: An agenda for developing countries. J. Open Innov. Technol. Mark. Complex. 2017, 3, 1-25. [CrossRef]

28. Svirina, A.; Zabbarova, A.; Oganisjana, K. Implementing open innovation concept in social business. J. Open Innov. Technol. Mark. Complex. 2016, 2, 1-20. [CrossRef]

29. Utterback, J.M. The process of technological innovation within the firm. Acad. Manag. J. 1971, 14, 75-88.

30. Zaltman, G.; Duncan, R.; Holbek, J. Innovations and Organizations; New York Wiley: New York, NY, USA, 1973. 
31. Schumpeter, J. Creative destruction. Capital. Social. Democr. 1942, 825, 82-85.

32. Barro, R.J.; Lee, J.W. A new data set of educational attainment in the world 1950-2010. J. Dev. Econ. 2013, 104, 184-198. [CrossRef]

33. Wright, P.M.; McMahan, G.C.; McWilliams, A. Human resources and sustained competitive advantage: A resource-based perspective. Int. J. Hum. Resour. Manag. 1994, 5, 301-326. [CrossRef]

34. Hambrick, D.C.; Mason, P.A. Upper echelons: The organization as a reflection of its top managers. Acad. Manag. Rev. 1984, 9, 193-206. [CrossRef]

35. Finkelstein, S.; Hambrick, D.C.; Cannella, A.A. Strategic Leadership; West Educational Publishing: St. Paul, MN, USA, 1996.

36. Simons, T.; Pelled, L.H.; Smith, K.A. Making use of difference: Diversity, debate, and decision comprehensiveness in top management teams. Acad. Manag. J. 1999, 42, 662-673.

37. Roure, J.B.; Keeley, R.H. Predictors of success in new technology based ventures. J. Bus. Ventur. 1990, 5, 201-220. [CrossRef]

38. Hambrick, D.C.; Cho, T.S.; Chen, M.J. The influence of top management team heterogeneity on firms' competitive moves. Admin. Sci. Q. 1996, 41, 659-684. [CrossRef]

39. Bantel, K.A.; Jackson, S.E. Top management and innovations in banking: Does the composition of the top team make a difference? Strateg. Manag. J. 1989, 10, 107-124. [CrossRef]

40. Vroom, V.H.; Pahl, B. Relationship between age and risk taking among managers. J. Appl. Psychol. 1971, 55, 399. [CrossRef]

41. Chae, H.W.; Song, J.Y. The impact of top management team demography on technological innovations in high-technology firms. Strateg. Manag. J. 2009, 12, 83-104. [CrossRef]

42. Song, J.Y.; An, K.J.; Chae, H.W.; Cho, T.S. The effects of founder-CEO attributes on alliance formation of venture startups: A social network perspective. Korean Manag. Rev. 2009, 38, 1545-1572.

43. Eisenhardt, K.M.; Schoonhoven, C.B. Resource-based view of strategic alliance formation: Strategic and social effects in entrepreneurial firms. Organ. Sci. 1996, 7, 136-150. [CrossRef]

44. Ryu, S.Y. The impact of group diversity and Kunja leadership on group performance. Korean J. Ind. Organ. Psy. 2012, 25, 27-58.

45. Jiang, C.S.; Zhou, Z.Y. The impact of intangible resources on competitive advantages. China's Circ. Econ. 2013, 6, 80-85.

46. Guan, J.; Ma, N. Innovative capability and export performance of Chinese firms. Technovation 2003, 23, 737-747. [CrossRef]

47. Ban, H.J. The impact of internal resources of firm on internationalization strategy: Focused on resource-based view. Korea Trade Rev. 2008, 33, 357-380.

48. Hwang, B.; Jun, H.; Chang, M.; Kim, D. A case study on the improvement of institution of "High-Risk High-Return R\&D" in Korea. J. Open Innov. Technol. Mark. Complex. 2017, 3, 1-19.

49. Liu, L. Influencing factors of enterprise R\&D investment: Theoretical analysis based on resource view. China Sci. Tech. Forum 2003, 11, 75-78.

50. Park, J.H.; Lee, B.; Moon, Y.H.; Kim, G.; Kwon, L.N. Relation of R\&D expense to turnover and number of listed companies in all industrial fields. J. Open Innov. Technol. Mark. Complex. 2018, 4, 1-9.

51. Peng, M.W.; Luo, Y. Managerial ties and firm performance in a transition economy: The nature of a micro-macro link. Aca. Manag. J. 2000, 43, 486-501.

52. Luo, Y. Guanxi and performance of foreign-invested enterprises in China: An empirical inquiry. Manag. Int. Rev. 1997, 37, 51-70.

53. From fiefs to clans and network capitalism: Explaining China's emerging economic order. In Knowledge, Organization, and Management: Building on the Work of Max Boisot; Boisot, M.; Child, J. (Eds.) Oxford University Press: Oxford, UK, 2013.

54. Yau, O.H. Chinese cultural values: Their dimensions and marketing implications. Eur. J. Mark. 1988, 22, 44-57. [CrossRef]

55. Kim, H.M.; Park, B.S.; Kim, J.I.; Kim, S.E.; Lee, J.; Oh, S.C.; Lee, J.O. Crystal structure of the TLR4-MD-2 complex with bound endotoxin antagonist Eritoran. Cell 2007, 130, 906-917. [CrossRef] [PubMed]

56. Xin, K.K.; Pearce, J.L. Guanxi: Connections as substitutes for formal institutional support. Acad. Manag. J. 1996, 39, 1641-1658. 
57. Kong, F.P.; Xu, X.Y. Study on the Impact of Government Science and Technology Inputs in Enterprise Technology Innovation. Ph.D. Thesis, Shandong University, Jinan, China, 2015.

58. Fock, H.K.; Woo, K.S. The China market: Strategic implications of guanxi. Bus. Strateg. Rev. 1998, 9, $33-43$. [CrossRef]

59. Hunt, S.D.; Morgan, R.M. The comparative advantage theory of competition. J. Mark. 1995, 59, 1-15. [CrossRef]

60. Park, S.H.; Luo, Y. Guanxi and organizational dynamics: Organizational networking in Chinese firms. Strateg. Manag. J. 2001, 22, 455-477. [CrossRef]

61. Gao, Y.Y.; Huang, G.L. Government Intervention and Insider Control and Corporate Diversity Research. Tech. Econ. Manag. Res. 2015, 3, 43-47.

62. Zhou, Z.Y.; Meng, W.D. The Theory and Empirical Study of Competitive Advantages of Enterprises Based on Intangible Resources. Ph.D. Thesis, Chongqing University, Chongqing, China, 2010.

63. Kliewer, W.; Dibble, A.E.; Goodman, K.L.; Sullivan, T.N. Physiological correlates of peer victimization and aggression in African American urban adolescents. Dev. Psychopathol. 2012, 24, 637-650. [CrossRef]

64. Chen, W.X.; Shen, Q.H. Resources, Capabilities, Governance Structure and National Industrial Development: Theoretical Analysis of China's Industrial Capability Evolution. Master's Thesis, Tsinghua University, Beijing, China, 2005.

65. Hu, J.H.; Miller, S.M.; Geurts, M.H.; Tang, W.; Chen, L.; Sun, N.; Liu, D.R. Evolved Cas9 variants with broad PAM compatibility and high DNA specificity. Nature 2018, 556, 57. [CrossRef]

66. Li, W.Q.; Lu, W.; Cui, H.M. Theory and Countermeasures of Government Finance Supporting the Development of High and New Technology. China Admin. 2012, 5, 51-53.

67. Teachman, J.D. Analysis of population diversity: Measures of qualitative variation. Soc. Methods Res. 1980, 8, 341-362. [CrossRef]

68. Seo, J.I.; Chang, H.W. CEO characteristics and firm R\&D investment: The moderating role of TMT characteristics and ownership structure. Strateg. Manag. J. 2010, 13, $29-49$.

69. Daniels, J.D.; Bracker, J. Profit performance: Do foreign operations make a difference? Manag. Int. Rev. 1989, $29,46$.

70. Ramaswamy, V.; DeSarbo, W.S.; Reibstein, D.J.; Robinson, W.T. An empirical pooling approach for estimating marketing mix elasticities with PIMS data. Mark. Sci. 1993, 12, 103-124. [CrossRef]

71. Sambharya, R.B. The combined effect of international diversification and product diversification strategies on the performance of US-based multinational corporations. Manag. Int. Rev. 1995, 35, 197-218.

72. Almeida, P. Knowledge sourcing by foreign multinationals: Patent citation analysis in the US semiconductor industry. Strateg. Manag. J. 1996, 17, 155-165. [CrossRef]

73. Suh, Y.; You, J.; Kim, P. The effect of innovation capabilities and experience on cross-border acquisition performance. Glob. J. Bus. Res. 2013, 7, 59-74.

74. Rothaermel, F.T.; Deeds, D.L. Exploration and exploitation alliances in biotechnology: A system of new product development. Strateg. Manag. J. 2004, 25, 201-221. [CrossRef]

75. Mosakowski, E. Organizational boundaries and economic performance: An empirical study of entrepreneurial computer firms. Strateg. Manag. J. 1991, 12, 115-133. [CrossRef]

76. O'Reilly, C.A., III; Tushman, M.L. Organizational ambidexterity: Past, present, and future. Acad. Manag. Perspect. 2013, 27, 324-338. [CrossRef]

77. Yoo, J.; Kim, J. The Effects of Entrepreneurial Orientation and Environmental Uncertainty on Korean Technology Firms' R\&D Investment. J. Open Innov Tech. Mark. Complexity. 2019, 5, 29.

78. Salvador, F.; Villena, V.H. Supplier integration and NPD outcomes: Conditional moderation effects of modular design competence. J. Supply Chain Manag. 2013, 49, 87-113. [CrossRef]

79. Hayes, A.F. Introduction to Mediation, Moderation, and Conditional Process Analysis: A Regression-Based Approach; The Guilford Press: New York, NY, USA, 2013; pp. 335-337.

80. Xiao, P.; Sun, Y.H. Research on the Relationship between Chinese Enterprises' Internationalization and Innovation Performance under the New Normal. Sci. Technol. Prog. Policy 2015, 11, 104-107.

81. Zeng, T.; Deng, T.Z. The relationship between the degree of internationalization of enterprises and technological innovation: A relationship of learning. J. Int. Trade 2012, 10, 59-85.

82. Pelled, L.H. Demographic diversity, conflict, and work group outcomes: An intervening process theory. Org. Sci. 1996, 7, 615-631. [CrossRef] 
83. Holl, A.; Rama, R. Technology sourcing: Are biotechnology firms different? An exploratory study of the Spanish case. Sci. Public Policy 2012, 39, 304-317. [CrossRef]

84. Rothaermel, F.T.; Hess, A.M. Building dynamic capabilities: Innovation driven by individual-, firm--, and network-level effects. Org. Sci. 2007, 18, 898-921. [CrossRef]

85. Ahuja, G. Collaboration networks, structural holes, and innovation: A longitudinal study. Admin. Sci. $Q$. 2000, 45, 425-455. [CrossRef]

86. Stuart, T.E. Interorganizational alliances and the performance of firms: A study of growth and innovation rates in a high-technology industry. Strateg. Manag. J. 2000, 21, 791-811. [CrossRef]

(C) 2019 by the authors. Licensee MDPI, Basel, Switzerland. This article is an open access article distributed under the terms and conditions of the Creative Commons Attribution (CC BY) license (http://creativecommons.org/licenses/by/4.0/). 